\title{
Intentional versus unintentional nitrogen use in the United States: trends, efficiency and implications
}

\author{
Benjamin Z. Houlton • Elizabeth Boyer • Adrien Finzi • James Galloway • \\ Allison Leach • Daniel Liptzin · Jerry Melillo • Todd S. Rosenstock • \\ Dan Sobota $\cdot$ Alan R. Townsend
}

Received: 1 June 2012/ Accepted: 27 September 2012/Published online: 13 October 2012

(C) The Author(s) 2012. This article is published with open access at Springerlink.com

\begin{abstract}
Human actions have both intentionally and unintentionally altered the global economy of nitrogen $(\mathrm{N})$, with both positive and negative consequences for human health and welfare, the environment and climate change. Here we examine long-term trends in reactive $\mathrm{N}(\mathrm{Nr})$ creation and efficiencies of $\mathrm{Nr}$ use within the continental US. We estimate that human actions in the US have increased $\mathrm{Nr}$ inputs by at least $\sim 5$ times compared to pre-industrial conditions.
\end{abstract}

B. Z. Houlton $(\varangle) \cdot$ D. Liptzin

University of California, Davis, CA, USA

e-mail: bzhoulton@ucdavis.edu

E. Boyer

Pennsylvania State University, University Park, PA, USA

A. Finzi

Boston University, Boston, MA, USA

J. Galloway · A. Leach

University of Virginia, Charlottesville, VA, USA

J. Melillo

Marine Biological Laboratory, Woods Hole, MA, USA

T. S. Rosenstock

The World Agroforestry Centre, Nairobi, Kenya

D. Sobota

National Research Council (with US EPA), Corvallis, OR, USA

A. R. Townsend

University of Colorado, Boulder, CO, USA
Whereas $\mathrm{N}_{2}$ fixation as a by-product of fossil fuel combustion accounted for $\sim 1 / 4$ of $\mathrm{Nr}$ inputs from the 1970s to 2000 (or $\sim 7 \mathrm{Tg} \mathrm{N}$ year $^{-1}$ ), this value has dropped substantially since then (to $<5 \mathrm{Tg} \mathrm{N}_{\text {year }}{ }^{-1}$ ), owing to Clean Air Act amendments. As of 2007, national $\mathrm{N}$ use efficiency (NUE) of all combined $\mathrm{N}$ inputs was equal to $\sim 40 \%$. This value increases to $55 \%$ when considering intentional $\mathrm{N}$ inputs alone, with food, industrial goods, fuel and fiber production accounting for the largest $\mathrm{Nr}$ sinks, respectively. We estimate that $66 \%$ of the $\mathrm{N}$ lost during the production of goods and services enters the air $\left(\right.$ as $\mathrm{NO}_{x}, \mathrm{NH}_{3}, \mathrm{~N}_{2} \mathrm{O}$ and $\mathrm{N}_{2}$ ), with the remaining $34 \%$ lost to various waterways. These $\mathrm{Nr}$ losses contribute to smog formation, acid rain, eutrophication, biodiversity declines and climate change. Hence we argue that an improved national NUE would: (i) benefit the US economy on the production side; (ii) reduce social damage costs; and (iii) help avoid some major climate change risks in the future.

Keywords Nitrogen - Climate - Efficiency · United States · Carbon · Phosphorus · Economics

\section{Introduction}

There are both positive and negative consequences of anthropogenic modification of all Earth's major biogeochemical cycles (Falkowski 1997). This is clear in the case of phosphorus (P), which has been heavily 
mined for crop fertilizer, but which leads to eutrophication as this element leaches from soils to freshwater ecosystems (Schindler 1977; Smil 2000; Bennett et al. 2001). A modified carbon (C) cycle, in which fossil fuel combustion has enhanced available energy and boosted economic prosperity, also creates a suite of problems such as climate change and ocean acidification (Hoegh-Guldberg et al. 2007). Similarly, human activities have greatly accelerated rates of reactive nitrogen ( $\mathrm{Nr}$; defined as all $\mathrm{N}$ forms other than $\mathrm{N}_{2}$ ) creation, principally for food, fiber, energy and industrial goods; but unwanted side-effects of $\mathrm{Nr}$ enhancement are now widespread in the air, water and on land (Vitousek et al. 1997; Galloway et al. 2008; Davidson et al. 2012). Here we examine several trade-offs to US Nr use, evaluating trends in $\mathrm{Nr}$ creation over time and estimating the efficiency with which $\mathrm{Nr}$ is used among different sectors of the US economy-food, fiber, energy and industry. We show that $\sim 45 \%$ of the USs intentionally created Nr. does not meet its intended economic purpose each year, thus heightening risks to human health and welfare, the environment, and climate change.

Nitrogen resources have a deep and checkered history in shaping human society (Vitousek et al. 1997). Nitrogen is necessary for food production and played a major role in the development of munitions during WWI (Erisman et al. 2008). The recognition of scarce Nr supplies in desert caliche and guano deposits in the late 1800s led to the Nobel winning HaberBosch process in 1913, in which $\mathrm{N}_{2}$ in air is chemically converted to $\mathrm{Nr}$ under intense heat and pressure. Other notable mechanisms of anthropogenic $\mathrm{Nr}$ enhancement have included the domestication of $\mathrm{N}_{2}$ fixing legumes for agriculture and the unintentional $\mathrm{Nr}$ creation during fossil fuel combustion (Galloway et al. 2004). When combined, these global modifications have more than doubled terrestrial $\mathrm{Nr}$ circulation, contributing to widespread eutrophication of estuaries, acid rain, biodiversity declines, climate change, tropospheric ozone production, and stratospheric ozonehole formation (Vitousek et al. 1997; Ravishankara et al. 2009; Compton et al. 2011; Davidson et al. 2012).

Anthropogenic enrichment of $\mathrm{Nr}$ has given rise to a host of social, political and scientific challenges. $\mathrm{Nr}$ is highly mobile in the environment (Delwiche 1970), meaning that a single atom of fixed $\mathrm{Nr}$ cascades through the land, air and water systems before it returns to the atmosphere as $\mathrm{N}_{2}$ (Galloway et al. 2003). Hence, tracking Nr through Earth's subsystems is difficult given the multitude of scales in which $\mathrm{N}$ forms cyclefrom days to millions of years (Schlesinger 2009). Yet, it is possible to estimate human $\mathrm{Nr}$ use efficiency (NUE) at annual time scales-and thereby guide strategies to help deal with Nr's longer-term cascade through the human health and environmental systems (e.g., Howarth et al. 2002; Winiwarter and Hettelingh 2011). While clear in theory, NUE has many different definitions in practice; for the purpose of our calculations here, we define NUE as the proportion of Nr input that is incorporated into an intended product.

Much of the past focus on NUE has been agronomic, pointing out increased losses of $\mathrm{Nr}$ along the chain of food production. For example, on average only $\sim 50 \%$ of the $\mathrm{Nr}$ applied as fertilizer is actually available for near-term crop production (Cassman et al. 2002), with $<\sim 5 \%$ of the initial $\mathrm{Nr}$ ending up in beef consumed in developed countries (Galloway and Cowling 2002). A model-based assessment found that agricultural regions vary substantially in NUE, with Sub-Saharan Africa exceeding $100 \%$ (meaning N is being removed from the soil) and developed nations $\sim 43 \%$ (Bouwman et al. 2005), a finding consistent with $\mathrm{Nr}$ mass-balance comparisons among developing versus developed nations (Vitousek et al. 2009). An extensive synthesis report indicated that the NUE of European agriculture (including synthetic $\mathrm{Nr}$ fertilizer, food and feed imports) has held steady at $\sim 30 \%$ since 2000 . Thus, vast improvements can be made in local, regional and global NUE_-although much less is known about total NUE for combined food, fiber, fuel and industrial goods production (but see Robertson et al. 2011 for discussion of $\mathrm{Nr}$ use in biofuels).

It is increasingly important to recognize that widespread changes to the $\mathrm{N}$ cycle have not happened in isolation. Quite the opposite: global climate change is happening rapidly, with major impacts on the environment already visible (e.g. Walther et al. 2002; Alley et al. 2005; Araújo et al. 2011), some of which overlap and potentially interact with $\mathrm{Nr}$ 's various effects (Compton et al. 2011). Similar to N, for instance, climate change has been implicated in the intensity and extent of coastal eutrophication and hypoxia (Rabalais et al. 2009); biodiversity declines (Clark and Tilman 2008); and air quality related problems associated with smog formation (Carter et al. 1979; Muller and Mendelsohn 2007). Elements like $P$ have similarly been altered to meet food demands; ecosystem-scale experiments indicate that this element is principal to 
the eutrophication of lakes (Schindler 1977; Schindler et al. 2008) and strongly controls rates of terrestrial $\mathrm{N}_{2}$ fixation (Houlton et al. 2008).

Where, when and how $\mathrm{Nr}$ and climate overlap is uncertain, yet arguments can be made for climate impacts mitigation via reductions in $\mathrm{Nr}$ use. Townsend et al. (2012) recently suggested that improved management of $\mathrm{Nr}$ (and $\mathrm{P}$ ) could reduce- or even eliminate-several risks associated with a rapidly changing climate, specifically eutrophication and air quality hazards. They argued that decreasing $\mathrm{Nr}$ to waterways would ultimately reduce coastal algal blooms, such that climate change impacts on stratification and intense hypoxia events could be greatly diminished. Likewise, cutting fossil fuel $\mathrm{Nr}$ emissions reduces smog formation, and so the risk of rising temperatures on this air quality problem might be reduced by dealing with excess Nr. Though theoretically promising, questions remain about the efficacy of this approach and whether practices that improve NUE can be envisaged without burdening the economy.

Here we analyze the USs NUE among the sectors of food, fiber, energy and industry, with the intention of improving our understanding of the effects of excess $\mathrm{Nr}$. This is not so much a test of Townsend et al.'s (2012) framework; rather, by examining the national NUE, our aim is to begin engaging, in quantitative terms, how much $\mathrm{Nr}$ escapes the production-stream in the US without ever being incorporated into an intended product. We separate our analysis into intentional versus unintentional $\mathrm{Nr}$, culminating in an overall NUE to contrast with intentional $\mathrm{Nr}$ use alone. The three phases of our analyses include: (1) historical trends in intentional versus unintentional $\mathrm{Nr}$ in the US; (2) NUE estimates for two different time points, 2002 and 2007 (to examine for any temporal variation), including the fraction of $\mathrm{Nr}$ that is intended for food, fiber, energy and industrial goods; (3) fates of $\mathrm{Nr}$ that are not assimilated into an intended sink and thereby lost to the air, land, and water.

\section{Methods}

Conceptual approach

We use mass-balance principles and pre-existing data in our analysis. The boundary condition for our assessment is the conterminous US; and we evaluate trends in of US $\mathrm{Nr}$ as far back as the data allow. Conceptually, we separate our analysis into three key components: background $\mathrm{Nr}$ from natural sources (i.e., natural $\mathrm{N}$ fixation, lightening); unintentional $\mathrm{Nr}$, or $\mathrm{Nr}$ that is created inadvertently during fossil fuel combustion; and intentional $\mathrm{Nr}$, which has been purposely enhanced for the production of goods and services (i.e., Haber-Bosch, cultivation of biological $\mathrm{N}_{2}$ fixation [BNF]).

Long-term trends

Cultivation-induced BNF (C-BNF) trends are based on two assumptions: (1) C-BNF is proportional to productivity and areal extent of cultivation (Herridge et al. 2008) and (2) $\mathrm{N}_{2}$ fixation by soybeans and alfalfa account for $>2 / 3$ of C-BNF in the US and thus reasonably represent long-term trends in C-BNF (Howarth et al. 2002). Data from the US Department of Agriculture (USDA) Census of Agriculture were used to calculate C-BNF in accordance with Herridge et al. (2008).

Data on trends for US Haber-Bosch $\mathrm{Nr}$ were collected from USGS Data Series 140 and annual USGS mineral N reports (Kelly and Matos 2011). USGS Data Series 140 contains estimates for total US $\mathrm{NH}_{3}$ consumption from 1943 to 2010; the long-term trend was calculated as the percentage change between 1943 and 2008. Two shorter trends were calculated in the same way (1943-1979 and 1980-2008) owing to clear differences in $\mathrm{Nr}$ fertilizer use among these periods. Estimates of the fraction of Haber-Bosch $\mathrm{Nr}$ used for fertilizer and non-fertilizer (i.e. industrial) purposes were derived from USGS Data Series 140 (Kelly and Matos 2011).

$\mathrm{Nr}$ deposition data were compiled from the National Atmospheric Deposition Program (NADP), the Clean Air Status and Trends Network (CASTNET), and the National Trends Network (NTN). Due to limited spatial distribution of CASTNET monitoring stations, only data from NADP/NTN stations were examined, as reported in Lehmann et al. (2011). Briefly, Lehmann et al. (2011) analyzed trends for NADP sites that were established before 1 December 1986 and continued until at least 30 November 2007 ( $n=151$ sites).

US NUE analysis

$N$ inputs by source

Natural pathways of $\mathrm{Nr}$ input include lightning strikes and natural BNF. Deposition of $\mathrm{Nr}$ via lightning 
strikes was taken as half the amount estimated for this path in North America in 1995 (see Lelieveld and Dentener 2000; Galloway et al. 2004). Natural BNF was calculated as the sum of ecosystem type-specific BNF rates determined from literature surveys (Science Advisory Board to the EPA [SAB] 2011). We note that these values may be at the high end of $\mathrm{N}$ fixation estimates (see Houlton et al. 2008; Wang and Houlton 2009; Vitousek et al. in press). We also assume that natural BNF is constant among years.

Intentional $\mathrm{Nr}$ inputs for 2002 and 2007 were calculated from USDA and Food and Agricultural Organization of the United Nations (FAO) data. Data describing national-level synthetic $\mathrm{Nr}$ fertilizer use were acquired from the FAO. National-level data on $\mathrm{Nr}$ used for industrial purposes (e.g., nylon, explosives, plastics) for 2002 and 2007 were also acquired from FAO. C-BNF was calculated by applying cropspecific per-area $\mathrm{C}$-BNF rates to area planted in specific N-fixing crops for 2002 and 2007 (SAB 2011; USDA 2011).

For 2002 and 2007, unintentional $\mathrm{Nr}$ creation via fossil fuel combustion was taken from the US Environmental Protection Agency's National Emissions Inventory (NEI, 2011a). Emissions are broken down by sources, including "transportation," "utility and industry," and "other."

\section{$N$ use data}

The following intended fates for $\mathrm{Nr}$ flows in the US were considered: energy, human food, fiber, and industrial products. Losses of $\mathrm{Nr}$ include: air $\left(\mathrm{N}_{2} \mathrm{O}\right.$, $\mathrm{NO}_{x}, \mathrm{NH}_{3}$, and $\mathrm{N}_{2}$ ), surface waters (total $\mathrm{Nr}$ ), and unknown sources, likely those associated with deep groundwater seepage.

The amount of $\mathrm{Nr}$ converted to ethanol-based fuel was calculated using annual records of corn production as based on USDA statistics (2011). We assume that $32 \%$ of corn devoted to ethanol production enters the animal production system as distillers grain (residue from ethanol production; Renewable Fuels Association 2011). We also assumed that distiller grain was enriched in $\mathrm{Nr}(\sim 3.8 \%)$ relative to unprocessed grain $(\sim 1.5 \%$; University of Minnesota 2011).

For 2007, the amount of $\mathrm{Nr}$ converted to human food was calculated from FAO data on domestic production and international trade of major food commodities (Leach and Galloway, unpublished data); we assumed that human food production was the same for 2002. $\mathrm{Nr}$ in fiber was calculated from the average $\mathrm{Nr}$ content of wood (Fox et al. 2006) and cotton (USDA 2011). National data on wood production was available for 2002 (Fox et al. 2006) and assumed to be similar to that in 2007. The amount of $\mathrm{Nr}$ incorporated into industrial products was calculated by multiplying estimates of $\mathrm{Nr}$ for industrial processes in 2002 and 2007 (FAO 2011) by 0.78 to account for $\mathrm{N}$ losses during the production phase (Febre Domene and Ayers 2001). This calculation represents an upper limit of industrial-based NUE, as it does not include $\mathrm{N}$ losses during the production of $\mathrm{N}$ fertilizer.

Estimates of $\mathrm{Nr}$ losses to the atmosphere were taken from the USEPAs NEI $\left(\mathrm{NO}_{x}\right.$ and $\left.\mathrm{NH}_{3} ; 2011 \mathrm{a}\right)$ and the USEPAs Greenhouse Gas Inventory $\left(\mathrm{N}_{2} \mathrm{O} ; 2011 \mathrm{~b}\right)$. Losses from specific sectors/industries are detailed in these reports. For 2002, leaching of $\mathrm{Nr}$ to surface waters was based on the USGS SPARROW model (Preston et al. 2011); we assumed that 2007 was the same as 2002.

Denitrification to $\mathrm{N}_{2}$ gas was calculated by multiplying national $\mathrm{N}_{2} \mathrm{O}$ emissions (USEPA 2011b) by the $\mathrm{N}_{2}-\mathrm{N}: \mathrm{N}_{2} \mathrm{O}-\mathrm{N}$ estimated for denitrification (Schlesinger 2009). We assumed that $90 \%$ of $\mathrm{N}_{2} \mathrm{O}$ emissions from agricultural soils originated from denitrification and that $60 \%$ of emissions from forest/unmanaged lands originated from denitrification (Opdyke et al. 2009). We calculated an upper and lower bound for denitrification based on $\mathrm{N}_{2}-\mathrm{N}: \mathrm{N}_{2} \mathrm{O}-\mathrm{N}$ ratios presented in Schlesinger (2009), Seitzinger et al. (2006) and Denman et al. (2007). Lower bound estimates of denitrification were based on a ratio of $1.7: 1 \mathrm{~mol}$ of $\mathrm{N}_{2}-\mathrm{N}: \mathrm{N}_{2} \mathrm{O}-\mathrm{N}$ for agricultural sources and a ratio of 1.04:1 for forest/unmanaged lands. Upper bound estimates are based on an $\mathrm{N}_{2}-\mathrm{N}: \mathrm{N}_{2} \mathrm{O}-\mathrm{N}$ of 12:1 for all land types (Seitzinger et al. 2006). The "unknown" pool was estimated by subtracting the sum of estimated fates (human products and environmental losses) from the total annual $\mathrm{Nr}$ input for 2002 and 2007.

\section{NUE calculations}

The efficiency of conversion of $\mathrm{Nr}$ into human products was calculated by dividing the sum of $\mathrm{Nr}$ in energy, human food, fiber, and industrial products over the sum of all natural, intentional, and unintentional $\mathrm{Nr}$ created 
in the US annually. We evaluated the efficiency by which intentional $\mathrm{Nr}$ is converted to human products by assuming that this source is the major input of $\mathrm{Nr}$ in human products (i.e., a very small portion of unintentional $\mathrm{Nr}$ enters human products).

\section{Results}

Long-term trends

\section{Intentional $N$ inputs}

Production of food, fiber, fuel, and industrial products such as nylon and explosives have substantially increased US (and global) $\mathrm{Nr}$ consumption since World War II (Galloway et al. 2008). In the US, the consumption of synthetic $\mathrm{Nr}$ fertilizers increased exponentially from $0.4 \mathrm{Tg}$ year $^{-1}$ in 1943 to a maximum of $17.1 \mathrm{Tg}$ in 1998 (Fig. 1a); from the 1940 s to the 1980s, the rate of fertilizer consumption grew at a rate of $11 \%$ per year. From 1980 onward, consumption leveled off substantially, converging on a mean value of $14.7 \pm 1.2 \mathrm{Tg}$ of $\mathrm{Nr}$ year $^{-1}$. Fertilizer consumption accounts for nearly $90 \%$ of the $\mathrm{Nr}$ consumed in the US and so total $\mathrm{Nr}$ use is similarly reflected in the overall trend (SAB 2011).

$\mathrm{Nr}$ inputs via C-BNF climbed steadily from 1924 and 2009, accounting for $\sim 1.0-9.4 \mathrm{Tg} \mathrm{N}$ year $^{-1}$, respectively (Fig. 1b). US agriculture transitioned from heavy reliance on C-BNF to dominance by fossil fuel-derived $\mathrm{Nr}$ fertilizers (i.e., Haber-Bosch) in the mid-1960s (cf. Fig. 1a, b). In itself, C-BNF has undergone a massive transition over the past 100 years (Fig. 1b); until the 1980s, alfalfa comprised the largest fraction of total C-BNF in the US, while C-BNF via soybean has consistently exceeded alfalfa since around 1990.

\section{Unintentional $N$ inputs}

Human activities-industrial, transportation, and agricultural - unintentionally emit $\mathrm{Nr}$ compounds into the atmosphere during the combustion of fossil fuels. With the growth of industry and internal combustion engines, $\mathrm{NO}_{x}$ emissions steadily rose throughout the middle of the twentieth century (Fig. 1c). Emissions more than tripled-from 2.0 to $7.0 \mathrm{Tg} \mathrm{N}$ year $^{-1}$ between 1940 and 1970, stabilized for the next
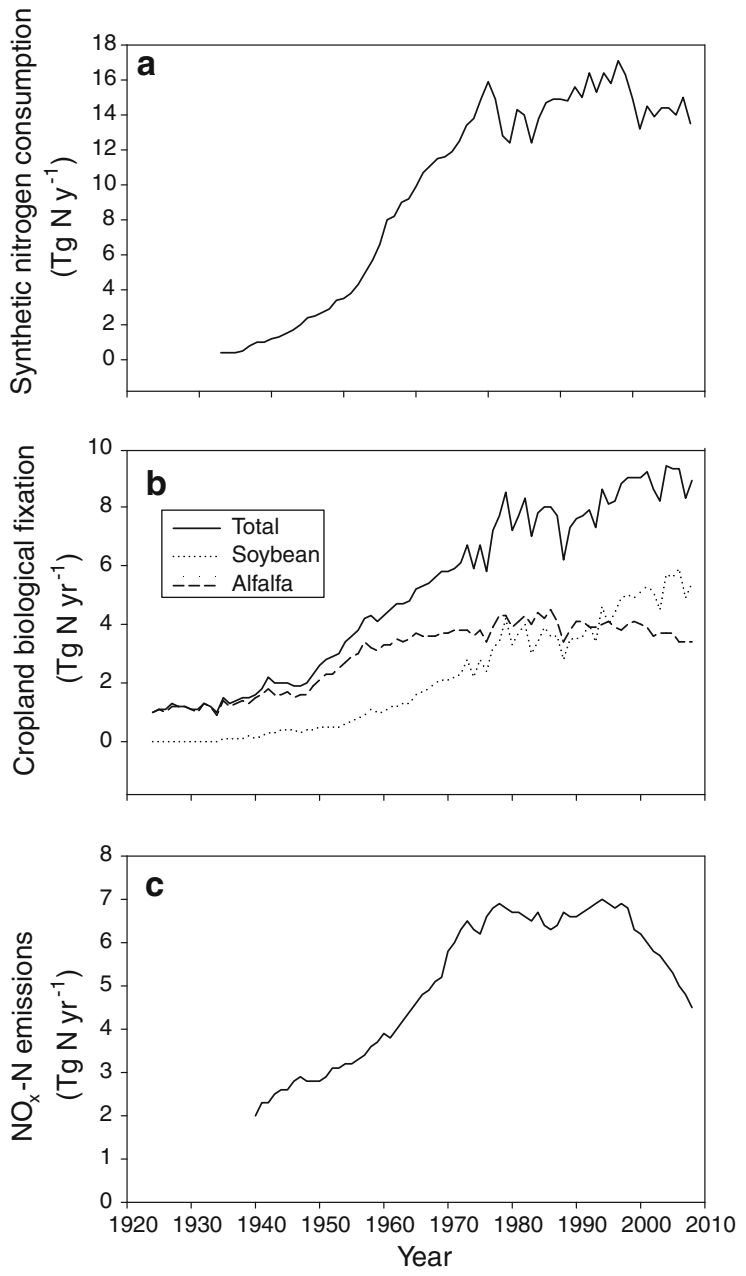

Fig. 1 Several nitrogen-based trends in the US. a Apparent consumption of synthetically fixed nitrogen (ammonia), 19432008. Apparent consumption $=$ production + imports - exports \pm stock changes (from Kelly and Matos 2011). b Di-nitrogen fixation by domesticated crops (alfalfa + soybean), 1924-2008 (from Sobota et al. in press). c Gaseous emissions of nitric oxides $\left(\mathrm{NO}_{x}\right), 1941-2008$ (from EPA NEI USEPA 2011a)

25 years, and then dropped substantially by the end of the century. In 2008, for example, $\mathrm{NO}_{x}$ emissions accounted for $4.5 \mathrm{Tg} \mathrm{N}$ year $^{-1}$, a level equivalent those observed for the mid-1960s in the US (Fig. 1c).

Although les comprehensive than for other $\mathrm{Nr}$ input paths, the NADP has been monitoring wet inorganic $\mathrm{Nr}$ deposition across 250 sites in the US since 1985 (Fig. 2). NADP sites exhibit regional variation in changes in Nr deposition (Fig. 2). From 1985 to 2009, wet $\mathrm{Nr}$ deposition rates dropped by $50 \%$ in parts of the Northeast (Fig. 2), consistent with reductions in $\mathrm{NO}_{x}$ emissions (Fig. 1c). However, $\mathrm{Nr}$ deposition rates have 
increased by $25-50 \%$ across parts of South- and Mountain-west, which may be partially due to increases in $\mathrm{NH}_{4}{ }^{+}$deposition (Lehmann et al. 2011).

\section{US NUE}

We estimated sources and fluxes of $\mathrm{Nr}$ in the US, calculating efficiencies of $\mathrm{Nr}$ incorporation into finite products (e.g., food, fiber, biofuel, and industrial goods). As above, we classify $\mathrm{Nr}$ inputs as intentional versus unintentional; any $\mathrm{Nr}$ that is not incorporated into the product is considered an annual loss-term, resulting in $\mathrm{N}$ leakage to the air, land and water. The losses thereby summarize the residual in our calculations of NUE, and include gaseous loss vectors such as $\mathrm{NO}_{x}, \mathrm{~N}_{2} \mathrm{O}, \mathrm{NH}_{3}$, and $\mathrm{N}_{2}$ and $\mathrm{NO}_{3}{ }^{-}$leaching. We recognize that this is a simplification based on set time-domain; as the $\mathrm{N}$ cascade model points out, each atom of $\mathrm{N}$ that is fixed will ultimately interact with all of Earth's systems. Nevertheless, the emphasis on intentional $\mathrm{Nr}$ creation that does not find its way into the intended product allows us to identify where $\mathrm{Nr}$ is being used most optimally. Our analysis focuses on two time points-2002 and 2007-providing information on any changes in $\mathrm{Nr}$ over time use as well as overall NUE.
In Table 1 we present the major fluxes of $\mathrm{N}$ in our analysis. We observed no major changes in $\mathrm{Nr}$ use between 2002 and 2007; the overall budget suggested only a slight increase in $\mathrm{Nr}$ flows to the US, over this time period. Natural $\mathrm{Nr}$ creation accounts for $6.5 \mathrm{Tg}$ $\mathrm{N}$ year $^{-1}$ of total $\mathrm{N}$ fixation in the US (SAB 2011), with the majority $\left(6.4 \mathrm{Tg} \mathrm{N}_{\mathrm{Near}}{ }^{-1}\right)$ originating from natural BNF as opposed to lightening strikes (Table 1). Intentional $\mathrm{Nr}$ creation accounts for $2 / 3$ (22.8-24.7 $\mathrm{Tg} \mathrm{N}_{\text {year }}{ }^{-1}$ ) of total $\mathrm{N}_{2}$ fixation in the US (Table 1; Fig. 3), while unintentional $\mathrm{Nr}$ creation contributes around $15-20 \%\left(4.8-5.9 \mathrm{Tg} \mathrm{N}_{\mathrm{Near}}{ }^{-1}\right)$ of total national $\mathrm{Nr}$ (Table 1; Fig. 3). Nearly two-thirds of unintentional $\mathrm{Nr}$ derives from vehicle use, while a majority of the remainder derives from fossil fuel combustion by stationary power plants, industrial boilers, and other similar processes (Fig. 3).

Approximately $75 \%$ of intentional $\mathrm{Nr}$ enters agricultural systems in the US for food, livestock feed, energy, and fiber production (Table 1; Fig. 3). Synthetic fertilizer comprises $2 / 3$ of $\mathrm{Nr}$ input to US agriculture, with the remainder originating from C-BNF. Industrial products like nylon and explosives account for the remaining $25 \%$ of intentionally fixed $\mathrm{Nr}$ in the US (Table 1; Fig. 3). Our knowledge about the ultimate fate of this $\mathrm{Nr}$ is especially uncertain.
Fig. 2 Trend in wet deposition of inorganic nitrogen, 1985-2009 (from Lehmann et al. 2011)

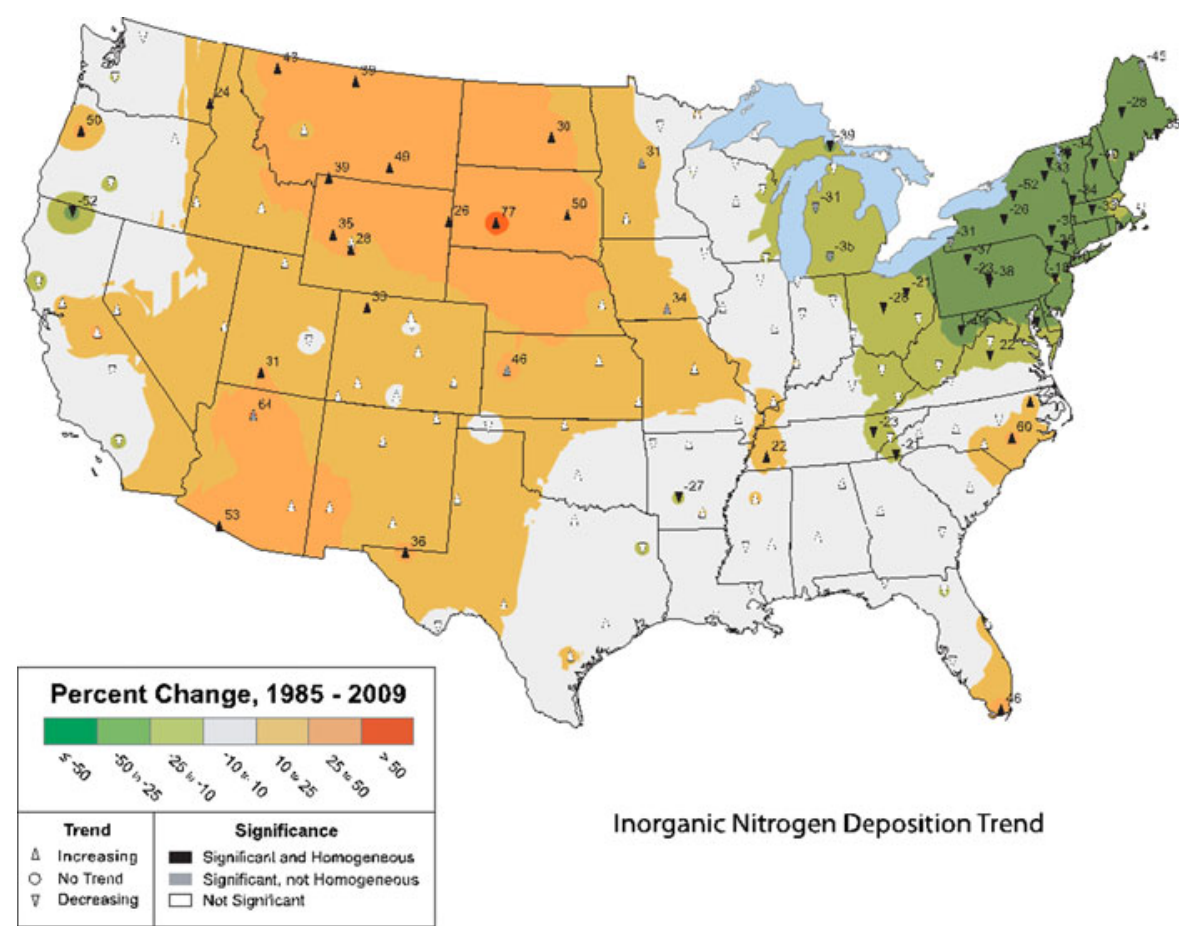


Table 1 N fixation in the US for 2002 and 2007

\begin{tabular}{|c|c|c|}
\hline & 2002 & 2007 \\
\hline \multicolumn{3}{|l|}{ Natural $\mathrm{N}$ fixation } \\
\hline Lightning $^{\mathrm{a}}$ & 0.1 & 0.1 \\
\hline $\mathrm{BNF}^{\mathrm{b}}$ & 6.4 & 6.4 \\
\hline Subtotal & 6.5 & 6.5 \\
\hline \multicolumn{3}{|l|}{ Intentional $\mathrm{N}$ fixation } \\
\hline \multicolumn{3}{|l|}{ Haber-Bosch N } \\
\hline Synthetic fertilizer ${ }^{c}$ & 10.9 & 11.4 \\
\hline Industrial production $^{\mathrm{c}}$ & 4.2 & 6.2 \\
\hline $\mathrm{N}$-fixing crop cultivation $(\mathrm{C}-\mathrm{BNF})^{\mathrm{b}}$ & 7.7 & 7.1 \\
\hline Subtotal & 22.8 & 24.7 \\
\hline \multicolumn{3}{|l|}{ Unintentional $\mathrm{N}$ fixation (emissions) } \\
\hline Fossil fuel combustion: transportation ${ }^{\mathrm{d}}$ & 3.6 & 3.0 \\
\hline Fossil fuel combustion: utility and industry ${ }^{\mathrm{d}}$ & 2.1 & 1.7 \\
\hline Other combustion $^{\mathrm{d}}$ & 0.2 & 0.1 \\
\hline Subtotal & 5.9 & 4.8 \\
\hline Grand total & 35.6 & 37.0 \\
\hline \multicolumn{3}{|l|}{ All values are in $\mathrm{Tg} \mathrm{N}$} \\
\hline \multicolumn{3}{|l|}{${ }^{\text {a }}$ Galloway et al. (2004) } \\
\hline \multirow{2}{*}{\multicolumn{3}{|c|}{$\begin{array}{l}\text { b SAB (2011), USDA (2011); } 2007 \text { C-BNF estimated using } \\
\text { SAB (2011) methods and USDA (2011) data }\end{array}$}} \\
\hline & & \\
\hline \multicolumn{3}{|l|}{ c FAO (2011) } \\
\hline \multicolumn{3}{|l|}{ d USEPA (2011a) } \\
\hline
\end{tabular}

On an annual basis, $\sim 30 \%$ of total $\mathrm{Nr}$ (unintentional and intentional $\mathrm{Nr}$ ) is incorporated into products; about the same amount is lost as $\mathrm{Nr}$ to the broader environment; approximately $2-15 \%$ is denitrified to $\mathrm{N}_{2}$; and the remaining $12-25 \%$ is lost to an unidentified $\operatorname{sink}(\mathrm{s})$ (Table 2; Fig. 3). As would be expected, intentional $\mathrm{Nr}$ use is much more efficient, with $\sim 55 \%$ entering food, livestock feed, biofuel (energy), and industrial products (Fig. 4). Spillover of intentional $\mathrm{Nr}$ is thus on the order of $45 \%$, with $27 \%$ lost to the environment as $\mathrm{Nr}$ along different pathways ( $\mathrm{Nr}$ in air and water), and an uncertain amount (3-21\%) escaping via inert $\mathrm{N}_{2}$ (Fig. 4). Assuming steady state, approximately $38 \%$ of agricultural $\mathrm{Nr}$ (synthetic fertilizer and fixation by leguminous crops) is used for human food and livestock feed, making it the dominant sink for intentional $\mathrm{Nr}$ in the US. Dinitrogen gas and hydrologic leaching account for the largest environmental losses of intentional $\mathrm{Nr}$ (Fig. 4); gaseous emissions of $\mathrm{NH}_{3}, \mathrm{NO}_{x}$, and $\mathrm{N}_{2} \mathrm{O}$ are smaller fates of intentional $\mathrm{Nr}$ in terms of total mass (Fig. 4).

\section{Discussion}

We examined the USs intentional versus unintentional NUE, and traced the fate of $\mathrm{Nr}$ that was not immediately incorporated into an intended sink (i.e., 1 - NUE/100), whether food, fiber, energy or industrial goods. Our overall assessment suggests that human actions in the US have increased $\mathrm{Nr}$ inputs by $\sim 5$ times compared to the natural $\mathrm{Nr}$ inputs, which are biological fixation and lightning strikes (Figs. 3, 4 ), and is likely a very conservative estimate of the relative increase (Vitousek et al. in press). This anthropogenic modification of $\mathrm{N}$ is at least twice as high as that observed globally (i.e., a doubling of terrestrial $\mathrm{Nr}$ creation; Vitousek et al. 1997), and is consistent with high per capita meat consumption in the US, which ranks in the top two or three nations worldwide (The Economist Online 2012).

Agriculture is the major $\mathrm{Nr}$ sink in the US, followed by industrial products, fuel and fiber (Fig. 4). The practice of applying $\mathrm{Nr}$ fertilizers at rates that greatly exceeds crop uptake is a growing problem in many developing and transitional countries; this practice, while improving as a whole in the US relative to peak inefficiencies of the 1980s (e.g. Vitousek et al. 2009), has clearly altered the US $\mathrm{N}$ cycle in unprecedented ways (Table 1). Moreover, $\mathrm{Nr}$ inputs to agriculture have continued to rise in the US (sum of Fig. 1a, b), while $\mathrm{NO}_{x}$ emissions have decreased precipitously owing to the Clean Air Act (Fig. 1c).

Though NUEs differed meaningfully by $\mathrm{Nr}$ source attribution (cf. Figs. 3, 4), we identified substantial inefficiencies in $\mathrm{Nr}$ use in all cases. On average, $>60 \%$ of the total $\mathrm{Nr}$ (background, intentional, unintentional) used or fixed (i.e., $36 \mathrm{Tg}$ ) in the US is lost (13 Tg) to the broader environment each year, or a combined NUE equal to $\sim 38 \%$. Considering that close to $11 \mathrm{Tg}$ of this $\mathrm{Nr}$ is not specifically intended for the production of economic goods and services (i.e., background plus unintentional $\mathrm{Nr}$ ), the NUE of intentional $\mathrm{Nr}$ is higher, approaching a value of $55 \%$. That $\sim 45 \%$ of intentional $\mathrm{Nr}$ escapes without ever being incorporated into a product portends an economic loss without any tangible benefit, an outcome made even worse give the externality costs of increased $\mathrm{Nr}$ on human health and the environment (Compton et al. 2011; Brink and van Grinsven 2011), and the longer-term and ultimate $\mathrm{N}$ cascade through all environmental systems (Galloway et al. 2003). 
Fig. 3 Nitrogen fixation and fates of $\mathrm{Nr}$ in the US for 2007. $B N F$ biological $\mathrm{N}$ fixation, $C-B N F$ crop biological $\mathrm{N}$ fixation, $H-B$ Haber-Bosch

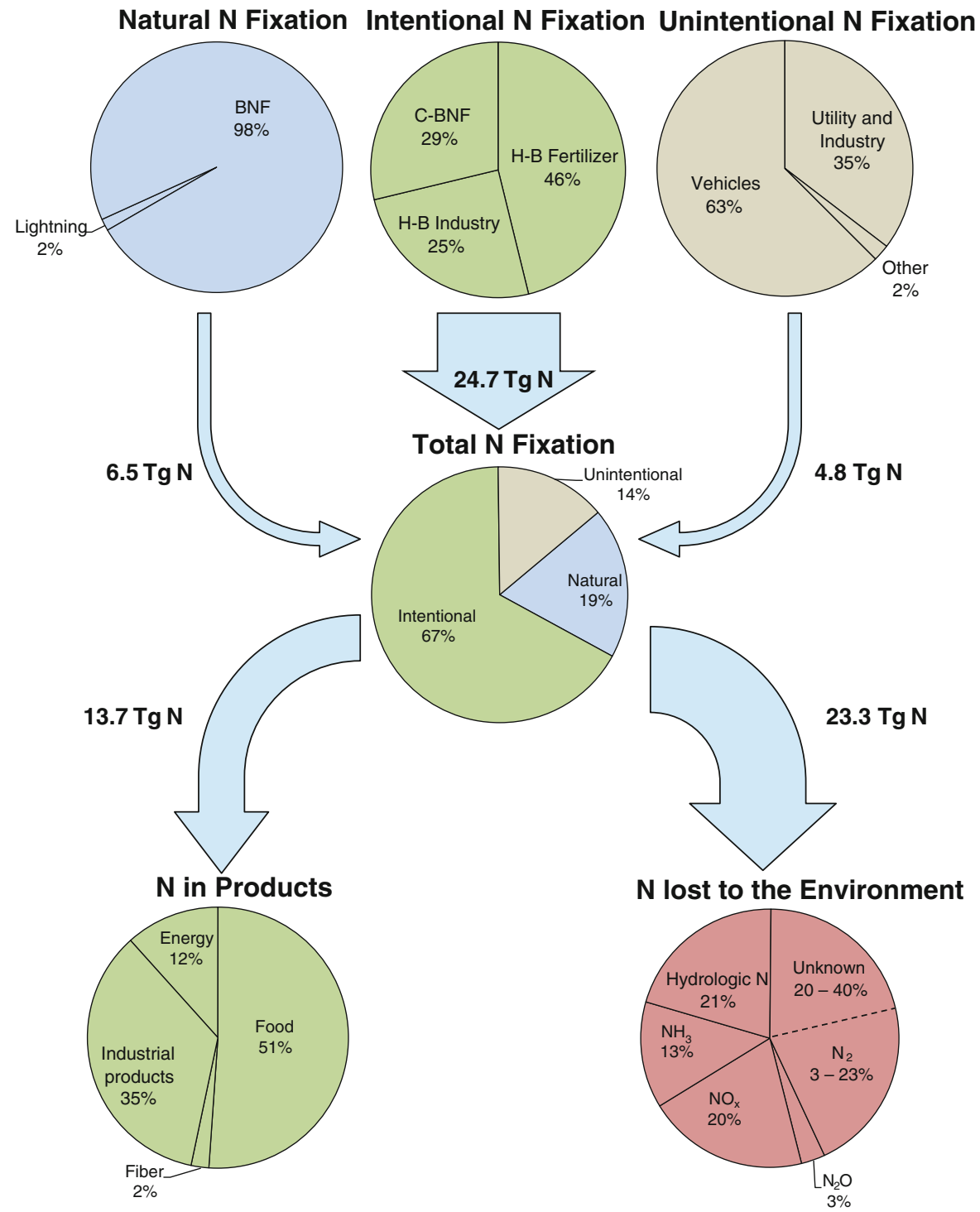

Anthropogenic $\mathrm{Nr}$ affects human health, welfare, and the environment, depending on its magnitude, form, and geographic distribution (Townsend et al. 2003; Sobota et al. in press). For the US, we estimate that $2 \%$ of intentional $\mathrm{Nr}$ escapes to the atmosphere as $\mathrm{N}_{2} \mathrm{O}$, where it contributes to directly to climate warming (Pinder et al. 2012); $13 \%$ to the hydrosphere where it contributes to eutrophication (Diaz and Rosenberg 2008) and drinking water risks (Ward et al. 2005); and $12 \%$ as $\mathrm{NO}_{x}$ and $\mathrm{NH}_{3}$ to the air where it contributes to poor air quality via tropospheric ozone and particulate matter (Muller and Mendelsohn 2007). A highly uncertain fraction-from 3 to $21 \%$ - of Nr is converted to $\mathrm{N}_{2}$, an effectively unreactive and stable form of $\mathrm{N}$ in the Earth system (see discussion below). On average, $\sim 66 \%$ of terrestrial $\mathrm{Nr}$ is lost to the atmosphere each year as a byproduct of intentional $\mathrm{Nr}$, with the remaining $34 \%$ lost to waterways (Fig. 4). This gas loss proportion is high when compared to the global average for unmanaged soil-systems ( $33 \%$; Houlton and Bai 2009), and suggests that anthropogenic modifications to the US $\mathrm{N}$ cycle have disproportionately increased airborne $\mathrm{Nr}$ emissions relative to dissolved $\mathrm{Nr}$ losses, similar to the case of many other industrialized nations (Bouwman et al. 2005).

Such $\mathrm{Nr}$ emissions can both cool and warm the climate system. A recent accounting suggests that anthropogenic $\mathrm{Nr}$ imparts net cooling of the US 
Table 2 Fates of N created in the US for 2002 and 2007

\begin{tabular}{|c|c|c|}
\hline & 2002 & 2007 \\
\hline \multicolumn{3}{|l|}{ Distribution of $\mathrm{N}$ by economic sector } \\
\hline Energy (corn-based biofuel) ${ }^{\mathrm{a}}$ & 1.1 & 1.6 \\
\hline \multicolumn{3}{|l|}{ Agriculture } \\
\hline Food $^{\mathrm{b}}$ & 7.0 & 7.0 \\
\hline Fiber $^{\mathrm{c}}$ & 0.3 & 0.3 \\
\hline Industrial products ${ }^{\mathrm{d}}$ & 3.2 & 4.8 \\
\hline Subtotal & 11.6 & 13.7 \\
\hline \multicolumn{3}{|l|}{$\mathrm{N}$ lost to the environment } \\
\hline \multicolumn{3}{|l|}{$\mathrm{N}_{2} \mathrm{O}$} \\
\hline Fossil fuel combustion ${ }^{\mathrm{e}}$ & 0.1 & 0.1 \\
\hline Industrial goods manufacturing $^{\mathrm{e}}$ & 0.05 & 0.05 \\
\hline Agricultural sources ${ }^{\mathrm{e}}$ & 0.5 & 0.5 \\
\hline Miscellaneous $^{\mathrm{e}}$ & 0.05 & 0.05 \\
\hline \multicolumn{3}{|l|}{$\mathrm{NO}_{x}$} \\
\hline Fossil fuel combustion ${ }^{\mathrm{f}}$ & 5.5 & 4.4 \\
\hline Agricultural/industrial sources ${ }^{\mathrm{f}}$ & 0.3 & 0.3 \\
\hline \multicolumn{3}{|l|}{$\mathrm{NH}_{3}$} \\
\hline Fossil fuel combustion ${ }^{\mathrm{f}}$ & 0.4 & 0.4 \\
\hline Agricultural/industrial sources ${ }^{\mathrm{f}}$ & 2.6 & 2.7 \\
\hline Surface water $\mathrm{N}^{\mathrm{g}}$ & 4.8 & 4.8 \\
\hline $\mathrm{N}_{2}^{\mathrm{h}}$ & $0.7-5.3$ & $0.8-5.4$ \\
\hline Unknown ${ }^{\mathrm{i}}$ & $4.4-9.0$ & $4.6-9.2$ \\
\hline Subtotal & 24 & 23.3 \\
\hline
\end{tabular}

Table 2 continued

\begin{tabular}{lll}
\hline & 2002 & 2007 \\
\hline Grand total & 35.6 & 37.0 \\
\hline
\end{tabular}

All values are in $\mathrm{Tg} \mathrm{N}$

a Data on corn consumption from the USDA (2011), Renewable Fuels Association (2011). N content of biofuel calculated from information presented by the University of Minnesota (2011)

b Leach and Galloway, unpublished data (assumed that 2002 is similar to 2007)

c Fox et al. (2006), USDA (2011)

d Assumes $22 \%$ of N created for industrial uses (FAO 2011) is lost as waste or emissions (derived from data in Febre Domene and Ayres 2001)

e USEPA (2011b)

${ }^{f}$ USEPA (2011a)

g SAB (2011)

${ }^{\mathrm{h}}$ Lower bound estimated by applying a ratio of 1.7:1 mol of $\mathrm{N}_{2}-\mathrm{N}: \mathrm{N}_{2} \mathrm{O}-\mathrm{N}$ generated via denitrification (Schlesinger 2009) to $\mathrm{N}_{2} \mathrm{O}$ emissions listed for denitrification-mediated agricultural sources listed in USEPA (2011a, b) and a ratio of 1.04:1 is assumed for forested land. Upper bound estimates are based on an $\mathrm{N}_{2}-\mathrm{N}: \mathrm{N}_{2} \mathrm{O}-\mathrm{N}$ of $12: 1$ and derive from comparison of global estimates of soil denitrification (Seitzinger et al. 2006) and Denman et al. (2007). For both lower and upper estimates, $90 \%$ of $\mathrm{N}_{2} \mathrm{O}$ emissions from agricultural lands are assumed to originate from denitrification; $60 \%$ is assumed to originate from denitrification in forest/ unmanaged lands (Opdyke et al. 2009)

i By difference

\section{Intentional N Fixation - 2007}

\section{7 $\operatorname{Tg} \mathrm{N}$}

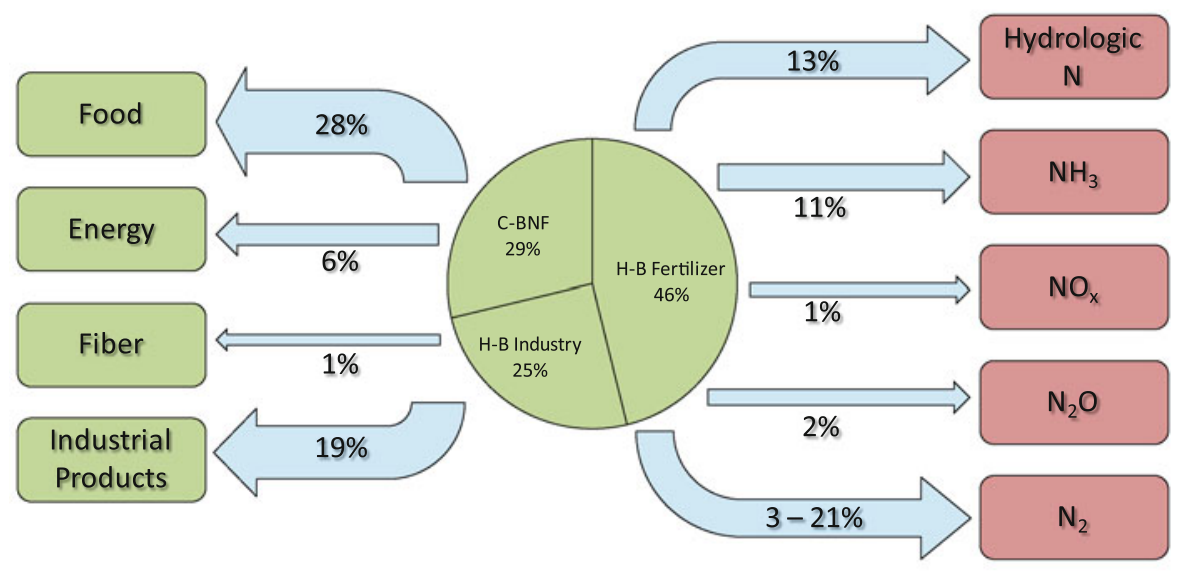

N in Products: $13.7 \mathrm{Tg} \mathbf{N}$

$\mathrm{N}$ lost to the Environment: $11.0 \mathrm{Tg} \mathrm{N}$

Fig. 4 Fates of intentional N fixation in the US for 2007. $C$ - $B N F$ crop biological N fixation, $H-B$ Haber-Bosch 
climate (Pinder et al. 2012; this issue), similar to observations for EU27 (Sutton and Billen 2011). As in most areas, the warming is largely due to intentional $\mathrm{Nr}$ and associated $\mathrm{N}_{2} \mathrm{O}$ in agriculture, with the cooling effects driven by $\mathrm{CO}_{2}$ uptake associated with unintentional fossil fuel $\mathrm{Nr}$ deposition on aggrading ecosystems (Hungate et al. 2003; Wang and Houlton 2009; Thomas et al. 2010; Pinder et al. 2012). One implication of intentional $\mathrm{Nr}$ warming and the transition to more intentional $\mathrm{Nr}$ compared to fossil fuel $\mathrm{NO}_{x}$ (Fig. 1a-c) is that the climate forcing of $\mathrm{Nr}$ is likely to change in the future, with warming effects eclipsing those of cooling effects in the US this century (Pinder et al. 2012).

Hence, our analysis advances the idea that $\mathrm{Nr}$ management reduces near-term climate risks for human health and the environment (Townsend et al. 2012). Consider, for example, that $13 \%$ of intentional $\mathrm{Nr}$ is lost to the aquatic system, where it contributes substantially to eutrophication and hypoxia of the Gulf of Mexico (Rabalais et al. 2007). Climate change is expected to worsen hypoxia, as increased temperatures lead to poor $\mathrm{O}_{2}$ ventilation of deep waters where $\mathrm{O}_{2}$ is most limiting to estuarine organisms (Rabalais et al. 2009). Yet, if $\mathrm{Nr}$ is used more efficiently in the US-particularly with the development and deployment of new fertilization practices, fertilizer technologies, and more $\mathrm{N}$ use efficient plant genotypes-the climate risks of excess $\mathrm{N}$ on eutrophication would be reduced, perhaps alleviated altogether. A similar case could be argued for air pollution effects in which elevated $\mathrm{NO}_{x}$ and increased warming greatly catalyze the formation of ground level $\mathrm{O}_{3}$; without the elevated $\mathrm{NO}_{x}$ in the atmosphere, the effect of rising temperature on $\mathrm{O}_{3}$ formation is greatly reduced if not ameliorated.

A key implication of our study is that, the NUEs we calculate point out $\mathrm{Nr}$ losses that short-circuit the stream of goods and services. Intentional $\mathrm{Nr}$ that escapes during production would seem to have no tangible economic benefit; a simple calculation suggests that the $\sim 11 \mathrm{Tg}$ of intentional $\mathrm{Nr}$ losses equates to $>\$ 6$ billion in US fertilizer costs alone. But the issue is more complex than this: what benefits the individual farmer is not necessarily the same as what benefits society as a whole. For example, rates of $\mathrm{Nr}$ application to grow crops and maximize profit at the farm-level are substantially higher than those which include the externality damages of excess $\mathrm{Nr}$ on human health and the environment (Brink and van
Grinsven 2011). Cost-benefit analysis suggests that the damages of agricultural $\mathrm{Nr}$ spillover (i.e., environmental and human health marginal damages) are on par with the economic benefits of intentional $\mathrm{Nr}$ use in EU27 (Brink and van Grinsven 2011), and air-borne $\mathrm{Nr}$ damages are estimated at $>\$ 16$ billion US (Muller and Mendelsohn 2007), with many other damages likely (Compton et al. 2011).

Marginal damages of $\mathrm{Nr}$ spillover are perhaps most acute in exported food: about $3 \mathrm{Tg}$ of food $\mathrm{Nr}$ were exported from the US in 2007 (FAO 2011), with $\mathrm{Nr}$ losses during production resulting in damages to the air and water, yet providing no benefit to US citizens in terms of food consumption. As the $\mathrm{N}$ cascade highlights, a single atom of $\mathrm{Nr}$ creation interactions with all systems-air, water, atmosphere-along its conversion back to effectively inert $\mathrm{N}_{2}$ (Galloway et al. 2003). Whereas much of the $\mathrm{Nr}$ used in agriculture can enter the air or water annually, $\mathrm{Nr}$ used to produce fiber and industrial goods turns over slowly, acting as short-term $\mathrm{Nr}$ sinks in the biosphere. Eventually all of the $\mathrm{N}_{2}$ fixed (intentionally or unintentionally) will affect the environment, and so even $\mathrm{Nr}$ incorporated into products has long-term effects.

Several existing approaches can help to reduce anthropogenic $\mathrm{Nr}$ losses to the air, land and water. The general categories include enhanced NUE measures in crop and animal production systems, mainly through enhanced root $\mathrm{Nr}$ uptake and calibration of $\mathrm{Nr}$ in animal feed; fertilization strategies that optimize the timing of $\mathrm{Nr}$ delivery to crops; improved $\mathrm{Nr}$ emissions reduction technologies; end-of-the-pipe solutions that convert $\mathrm{Nr}$ to $\mathrm{N}_{2}$ using such as riparian zones and wetlands; and individual-based dietary choices towards lowering meat consumption. Market based strategies are also an option, with cap-and-trade on $\mathrm{Nr}$ seemingly providing systemic incentives for the various $\mathrm{Nr}$ users nationwide. Whatever the approach, the best solution must be holistic, else $\mathrm{Nr}$ risks can outsource from one system to another (Sutton and Billen 2011). For example, work in Europe shows that management for reduced $\mathrm{Nr}$ leaching from animal manures can lead to greater airborne emissions of $\mathrm{NH}_{3}$ and air quality risks for human health (Velthof et al. 2009). We suggest that input-driven reductions are ultimately needed to stabilize $\mathrm{N}$ losses, given the propensity for $\mathrm{Nr}$ to mobilize rapidly across systems and the principle constraint of mass-balance. 
Our analysis also points to several research needs. First, we recommend further work focused on $\mathrm{N} \times$ climate interactions from the perspective of avoided climate change risks (Townsend et al. 2012). Quantitative socio-economic models that consider the full cost-benefits of reducing $\mathrm{N}$ over various scales, coupled to biogeochemical models that include multiple-organism and element interactions with the terrestrial, atmospheric, and aquatic systems are particularly needed. The tools to begin examining questions about $\mathrm{Nr}$ and climate risks are largely available (Brink and van Grinsven 2011); thus, future opportunities targeting such multi- and inter-disciplinary efforts are highly recommended.

Another opportunity lies in $\mathrm{N}_{2}$ emission-both scientifically and from a policy/management perspective. One of the notable uncertainties in our NUE calculation has to do with the amount of $\mathrm{N}_{2}$ associated with intentional $\mathrm{Nr}$ use. Denitrification is the most uncertain flux in the $\mathrm{N}$ cycle (Davidson and Seitzinger 2006; Schlesinger 2009; Houlton and Bai 2009); we estimate here that $\mathrm{N}_{2}$ may account for $3-21 \%$ of intentional $\mathrm{Nr}$ leakage. This level of uncertainty suggests a major research effort is needed to quantify $\mathrm{N}_{2}$ efflux from natural and managed sites. In terms of $\mathrm{NUE}$, any $\mathrm{Nr}$ that is not assimilated into an intended product is part of the inefficiency term in our calculations; however, $\mathrm{N}_{2}$ is by far the best fate for excess $\mathrm{Nr}$ in terms of its environmental effects. The difference between inert $\mathrm{N}_{2}$ and $\mathrm{Nr}$ further reinforces the importance of finding new ways to measure and assess $\mathrm{N}_{2}$ efflux, perhaps even enhancing this $\mathrm{N}$ loss pathway as a management lever (Schipper et al. 2010). On the other hand, there are clear economic advantages to reducing $\mathrm{Nr}$ losses no matter the fate.

Our calculations are reliant on existing data, and discrepancies among data sets have the potential to influence NUE calculations for the US and beyond. For example, 2007 estimates of $\mathrm{Nr}$ fertilizer consumption and industrial $\mathrm{N}_{2}$ fixation reported by the FAO were 11.4 and $6.2 \mathrm{Tg} \mathrm{N}$, respectively, versus 13.7 and $1.5 \mathrm{Tg}$ $\mathrm{N}$ for these same respective terms in USGS statistics. We relied on FAO data for our NUE calculations here, so as to provide consistency with recent US N budget assessments (SAB 2011). Future work should focus on understanding the source of discrepancy among data sources and any biases therein.

Finally, the effects of $\mathrm{Nr}$ on the broader environment are both temporally and spatially heterogeneous, with consequences varying from region to region (Sobota et al. in press). Semi-quantitative mapping of $\mathrm{Nr}$ fluxes across regions suggests that, whereas all US regions are likely to experience water quality related issues associated with $\mathrm{Nr}$ losses, $\mathrm{O}_{3}$-related air quality issues will be most pronounced in the Midwestern and Northeastern regions (Houlton et al. 2012). In terms of climate $\times \mathrm{N}$ interactions, the Midwest is by far the largest source of $\mathrm{N}_{2} \mathrm{O}$ to the atmosphere (Pinder et al. 2012). Targeted efforts to reduce excess $\mathrm{N}$ from agriculture would therefore not only benefit water quality, decrease coastal eutrophication and improve air quality, but would aid significantly in greenhouse gas mitigation. From a $\mathrm{C}$ storage perspective, the possible benefits of excess $\mathrm{Nr}$ are generally associated with forests in the Northeast and Northwest regions; the location of the largest C sink in the Northeastern US is at least partially driven by atmospheric transport of unintentional $\mathrm{Nr}$ associated with fossil fuel combustion (Townsend et al. 1996; Thomas et al. 2010). However, this perceived benefit is likely to diminish in the future as $\mathrm{NO}_{x}$ emissions decline, $\mathrm{C}$ sinks saturates, and soils become acidic (Agren and Bosatta 1988; Aber et al. 1998).

Acknowledgments This work resulted from a workshop supported by NSF Research Coordination Network Awards DEB-0443439 and DEB-1049744 and by the David and Lucille Packard Foundation.

Open Access This article is distributed under the terms of the Creative Commons Attribution License which permits any use, distribution, and reproduction in any medium, provided the original author(s) and the source are credited.

\section{References}

Aber J, McDowell W, Nadelhoffer K, Magill A, Berntson G, Kamakea M, McNulty S, Currie W, Rustad L, Fernandez I (1998) Nitrogen saturation in temperate forest ecosystems-hypotheses revisited. Bioscience 48(11):921-934

Agren GI, Bosatta E (1988) Nitrogen saturation of terrestrial ecosystems. Environ Pollut 54(3-4):185-197

Alley RB, Clark PU, Huybrechts P, Joughin I (2005) Ice-sheet and sea-level changes. Science 310(5747):456-460

Araújo MB, Alagador D, Cabeza M, Nogués-Bravo D, Thuiller W (2011) Climate change threatens European conservation areas. Ecol Lett 14(5):484-492

Bennett EM, Carpenter SR, Caraco NF (2001) Human impact on erodible phosphorus and eutrophication: a global perspective. Bioscience 51(3):227-234

Bouwman AF, Van Drecht G, Van der Hoek KW (2005) Global and regional surface nitrogen balances in intensive 
agricultural production systems for the period 1970-2030. Pedosphere 15(2):137-155

Brink C, van Grinsven H (2011) Chapter 22: costs and benefits of nitrogen in the environment. In: Sutton MA (ed) The European nitrogen assessment. Cambridge University Press, Cambridge

Carter WPL, Winer AM, Darnall KR, Pitts JN (1979) Smog chamber studies of temperature effects in photo-chemical smog. Environ Sci Technol 13(9):1094-1100

Cassman KG, Dobermann A, Walters DT (2002) Agroecosystems, nitrogen-use efficiency, and nitrogen management. Ambio 31(2):132-140

Clark CM, Tilman D (2008) Loss of plant species after chronic low-level nitrogen deposition to prairie grasslands. Nature 451(7179):712-715

Compton JE, Harrison JA, Dennis RL, Greaver TL, Hill BH, Jordan SJ, Walker H, Campbell HV (2011) Ecosystem services altered by human changes in the nitrogen cycle: a new perspective for US decision making. Ecol Lett 14(8):804-815

Davidson EA, Seitzinger S (2006) The enigma of progress in denitrification research. Ecol Appl 16(6):2057-2063

Davidson EA, David MB, Galloway JN, Goodale CL, Haeuber R, Harrison JA, Howarth RW, Jaynes DB, Lowrance RR, Nolan BT, Peel JL, Pinder RW, Porter E, Snyder CS, Townsend AR, Ward MH (2012) Excess nitrogen in the U.S. environment: trends, risks, and solutions. ESA Issues Ecol 15:1-16

Delwiche CC (1970) Nitrogen cycle. Sci Am 223(2):136-146

Denman KL, Brasseur G, Chidthaisong A, Ciais P, Cox P, Dickinson RE, Haugustaine D, Heinze C, Holland E, Jacob D, Lohmann U, Ramachandran S, da Silva Dias PL, Wofsy SC, Zhang X (2007) Couplings between changes in the climate system and biogeochemistry. In: Solomon SD, Manning QM, Chen Z, Marquis M, Averyt KB, Tignor M, Miller HL (eds) Climate change 2007: the physical science basis. Contribution of Working Group I to the Fourth Assessment Report of the Intergovernmental Panel on Climate Change. Cambridge University Press, Cambridge, pp 499-587

Diaz RJ, Rosenberg R (2008) Spreading dead zones and consequences for marine ecosystems. Science 321(5891): 926-929

Erisman JW, Sutton MA, Galloway J, Klimont Z, Winiwarter W (2008) How a century of ammonia synthesis changed the world. Nat Geosci 1(10):636-639

Falkowski PG (1997) Evolution of the nitrogen cycle and its influence on the biological sequestration of $\mathrm{CO}_{2}$ in the ocean. Nature 387:272-275

FAO (Food and Agricultural Organization of the United Nations) (2011) Fertilizer use statistics for the Food and Agricultural Organization of the United Nations http:// www.fao.org/ag/agl/fertistat/index_en.htm. Accessed Dec 2011

Febre Domene LA, Ayres RU (2001) Nitrogen's role in industrial systems. J Ind Ecol 5:77-103

Fox TR, Allen HL, Albaugh TJ, Rubilar R, Carlson CA (2006) Forest fertilization in Southern pine plantations. Better Crops Plant Food 90(2):12-15

Galloway JN, Cowling EB (2002) Reactive nitrogen and the world: 200 years of change. Ambio 31(2):64-71
Galloway JN, Aber JD, Erisman JW, Seitzinger SP, Howarth RW, Cowling EB, Cosby BJ (2003) The nitrogen cascade. Bioscience 53(4):341-356

Galloway JN, Dentener FJ, Capone DG, Boyer EW, Howarth RW, Seitzinger SP, Asner GP, Cleveland CC, Green PA, Holland EA, Karl DM, Michaels AF, Porter JH, Townsend AR, Vorosmarty CJ (2004) Nitrogen cycles: past, present, and future. Biogeochemistry 70(2):153-226

Galloway JN, Townsend AR, Erisman JW, Bekunda M, Cai ZC, Freney JR, Martinelli LA, Seitzinger SP, Sutton MA (2008) Transformation of the nitrogen cycle: recent trends, questions, and potential solutions. Science 320(5878):889-892

Herridge DF, Peoples MB, Boddey RM (2008) Global inputs of biological nitrogen fixation in agricultural systems. Plant Soil 311:1-18

Hoegh-Guldberg O, Mumby PJ, Hooten AJ, Steneck RS, Greenfield P, Gomez E, Harvell CD, Sale PF, Edwards AJ, Caldeira K, Knowlton N, Eakin CM, Iglesias-Prieto R, Muthiga N, Bradbury RH, Dubi A, Hatziolos ME (2007) Coral reefs under rapid climate change and ocean acidification. Science 318(5857):1737-1742

Houlton BZ, Bai E (2009) Imprint of denitrifying bacteria on the global terrestrial biosphere. Proc Natl Acad Sci USA 106(51):21713-21716

Houlton BZ, Wang YP, Vitousek PM, Field CB (2008) A unifying framework for dinitrogen fixation in the terrestrial biosphere. Nature 454(7202):327-334

Houlton BZ, Boyer E, Finzi A, Galloway J, Leach A, Liptzin D, Melillo J, Rosenstock T, Sobota D, Townsend AR (2012) Chap 2: The US nitrogen synthesis: N-use efficiency among economic sectors and $\mathrm{N}$ by climate risks nationwide. In: Suddick EC, Davidson EA (eds) The role of nitrogen in climate change and the impacts of nitrogenclimate interactions on terrestrial and aquatic ecosystems, agriculture, and human health in the United States. A technical report submitted to the US national climate assessment. Woods Hole Research Center, Falmouth, MA, pp 15-44

Howarth RW, Boyer EW, Pabich WJ, Galloway JN (2002) Nitrogen use in the United States from 1961-2000 and potential future trends. Ambio 31:88-96

Hungate B, Dukes J, Shaw M, Luo Y, Field C (2003) Nitrogen and climate change. Science 302(5650):1512-1513

Kelly TD, Matos GR (2011) Historical statistics for mineral and material commodities in the United States. US Geological Survey Data Series 140. Reston. http://minerals.usgs. gov/ds/2005/140/. Accessed Sep 2012

Lehmann CMB, Gay DA, Bowersox VC (2011) Trends in NADP/NTN precipitation chemistry and wet deposition, 1985-2009. Illinois State Water Survey. Prairie Research Institute, University of Illinois at Urbana-Champaign, Champaign

Lelieveld J, Dentener FJ (2000) What controls tropospheric ozone? J Geophys Res Atmos 105(D3):3531-3551

Muller NZ, Mendelsohn R (2007) Measuring the damages of air pollution in the United States. J Environ Econ Manag 54(1):1-14. doi:10.1016/j.jeem.2006.1012.1002

Opdyke MR, Ostrom NE, Ostrom PE (2009) Evidence for the predominance of denitrification as a source of $\mathrm{N}_{2} \mathrm{O}$ in temperate agricultural soils based on isotopologue 
measurements. Glob Biogeochem Cycl 23. doi:10.1029/ 2009GB003523

Pinder RW, Bettez ND, Bonan GB, Greaver TL, Wieder WR, Schlesinger WH, Davidson EA (2012) Impacts of human alteration of the nitrogen cycle in the US on radiative forcing. Biogeochemistry (this issue). doi:10.1007/ s10533-012-9787-z

Preston SD, Alexander RB, Schwarz GE, Crawford CG (2011) Factors affecting stream nutrient loads: a synthesis of regional SPARROW model results for the continental United States. J Am Water Resour Assoc 47(5):891-915

Rabalais NN, Turner RE, Sen Gupta BK, Platon E, Parsons ML (2007) Sediments tell the history of eutrophication and hypoxia in the Northern Gulf of Mexico. Ecol Appl 17(5): S129-S143

Rabalais NN, Turner RE, Diaz RJ, Justic D (2009) Global change and eutrophication of coastal waters. ICES J Mar Sci 66(7):1528-1537

Ravishankara AR, Daniel JS, Portmann RW (2009) Nitrous oxide $\left(\mathrm{N}_{2} \mathrm{O}\right)$ : the dominant ozone-depleting substance emitted in the 21st century. Science 326(5949):123-125

Renewable Fuels Association (2011) Ethanol facts: agriculture. http://www.ethanolrfa.org/pages/ethanol-facts-agriculture. Accessed Sep 2011

Robertson GP, Hamilton SK, Del Grosso SJ, Parton WJ (2011) The biogeochemistry of bioenergy landscapes: carbon, nitrogen, and water considerations. Ecol Appl 21(4): $1055-1067$

SAB (Science Advisory Board to the EPA) (2011) Reactive nitrogen in the United States; an analysis of inputs, flows, consequences, and management options. USEPA, Washington, DC

Schindler DW (1977) Evolution of phosphorus limitation in lakes. Science 184:897-899

Schindler DW, Hecky RE, Findlay DL, Stainton MP, Parker BR, Paterson MJ, Beaty KG, Lyng M, Kasian SEM (2008) Eutrophication of lakes cannot be controlled by reducing nitrogen input: results of a 37-year whole-ecosystem experiment. Proc Natl Acad Sci 105(32):11254-11258

Schipper LA, Gold AJ, Davidson EA (2010) Managing denitrification in human-dominated landscapes. Ecol Eng 36: 1503-1506

Schlesinger WH (2009) On the fate of anthropogenic nitrogen. Proc Natl Acad Sci USA 106(1):203-208

Seitzinger S, Harrison JA, Bohlke JK, Bouwman AF, Lowrance R, Peterson B, Tobias C, Van Drecht G (2006) Denitrification across landscapes and waterscapes: a synthesis. Ecol Appl 16(6):2064-2090

Smil V (2000) Phosphorus in the environment: natural flows and human interferences. Annu Rev Energy Environ 25:53-88

Sobota DJ, Compton JE, Harrison JA (In press) Reactive nitrogen inputs to land and waterways in the United States: How certain are we about sources and fluxes? Front Ecol Environ

Sutton MA, Billen G (2011) Technical summary. In: Sutton MA (ed) The European nitrogen assessment. Cambridge University Press, Cambridge

The Economist Online (2012) King of the carnivores. The Economist. http://www.economist.com/blogs/graphicdetail/ 2012/04/daily-chart-17. Accessed 25 Sep 2012
Thomas RQ, Canham CD, Weathers KC, Goodale CL (2010) Increased tree carbon storage in response to nitrogen deposition in the US. Nat Geosci 3:13-17

Townsend AR, Braswell BH, Holland EA, Penner JE (1996) Spatial and temporal patterns in terrestrial carbon storage due to deposition of fossil fuel nitrogen. Ecol Appl 6(3): 806-814

Townsend AR, Howarth RW, Bazzaz FA, Booth MS, Cleveland CC, Collinge SK, Dobson AP, Epstein PR, Keeney DR, Mallin MA, Rogers CA, Wayne P, Wolfe AH (2003) Human health effects of a changing global nitrogen cycle. Front Ecol Environ 1(5):240-246

Townsend AR, Vitousek PM, Houlton BZ (2012) The climate benefits of better nitrogen and phosphorus management. Issues Sci Technol 28(2):85-91

University of Minnesota (2011) Distillers grains by-products in livestock and poultry feeds. http://www.ddgs.umn.edu/ profiles-current.htm. Accessed Sep 2011

USEPA (US Environmental Protection Agency) (2011a) National Emissions Inventory (NEI) air pollutant emissions trends data. http://www.epa.gov/ttn/chief/trends/ index.html. Accessed Dec 2011

USEPA (US Environmental Protection Agency) (2011b) Inventory of U.S. greenhouse gas emissions and sinks: 1990-2009. Report EPA 430-R-11-005. Washington, DC

USDA (US Department of Agriculture) (2011) Census of Agriculture. http://www.agcensus.usda.gov/. Accessed Dec 2011

Velthof GL, Oudendag D, Witzke HR, Asman WAH, Klimont Z, Oenema O (2009) Integrated assessment of nitrogen losses from agriculture in EU-27 using MITERRA-EUROPE. J Environ Qual 38(2):402-417

Vitousek PM, Aber JD, Howarth RW, Likens GE, Matson PA, Schindler DW, Schlesinger WH, Tilman DG (1997) Human alteration of the global nitrogen cycle: sources and consequences. Ecol Appl 7(3):737-751

Vitousek PM, Naylor R, Crews T, David MB, Drinkwater LE, Holland E, Johnes PJ, Katzenberger J, Martinelli LA, Matson PA, Nziguheba G, Ojima D, Palm CA, Robertson GP, Sanchez PA, Townsend AR, Zhang FS (2009) Nutrient imbalances in agricultural development. Science 324(5934): $1519-1520$

Vitousek PM, Menge DNL, Reed SC, Cleveland CC (in press) Biological nitrogen fixation: rates, patterns and ecological controls in terrestrial ecosystems. Philos Trans R Soc B

Walther GR, Post E, Convey P, Menzel A, Parmesan C, Beebee TJC, Fromentin JM, Hoegh-Guldberg O, Bairlein F (2002) Ecological responses to recent climate change. Nature 416(6879):389-395

Wang YP, Houlton BZ (2009) Nitrogen constraints on terrestrial carbon uptake: implications for the global carbon-climate feedback. Geophys Res Lett 36, L24403. doi:10.1029/ 2009GL041009

Ward MH, deKok TM, Levallois P, Brender J, Gulis G, Nolan BT, VanDerslice J (2005) Workgroup report: drinking-water nitrate and health-recent findings and research needs. Environ Health Perspect 113(11):1607-1614

Winiwarter W, Hettelingh J-P (2011) Chapter 24: future scenarios of nitrogen in Europe. In: Sutton M (ed) The European nitrogen assessment. Cambridge University Press, Cambridge 